\title{
POLYMER COMPOSITES MODIFIED BY WASTE MATERIALS CONTAINING WOOD FIBRES
}

\author{
Bernardeta Dębska', Lech Lichołai', Patryk Godek' \\ 1 Faculty of Civil and Environmental Engineering and Architecture, Rzeszow University of Technology, Rzeszow, \\ Poland, e-mail: bdebska@prz.edu.pl
}

Received: 2016.08.16 Accepted: 2016.09.26 Published: 2016.11.01

\begin{abstract}
In recent years, the idea of sustainable development has become one of the most important requirements of civilization. Development of sustainable construction involves the need for the introduction of innovative technologies and solutions that will combine beneficial economic effects with taking care of the health and comfort of users, reducing the negative impact of the materials on the environment. Composites obtained from the use of waste materials are part of these assumptions. These include modified epoxy mortar containing waste wood fibres, described in this article. The modification consists in the substitution of sand by crushed waste boards, previously used as underlays for panels, in quantities of $0 \%, 10 \%, 20 \%, 35 \%$ and $50 \%$ by weight, respectively. Composites containing up to $20 \%$ of the modifier which were characterized by low water absorption, and good mechanical properties, also retained them after the process of cyclic freezing and thawing.
\end{abstract}

Keywords: polymer composites, epoxy mortars, waste materials, mechanical properties 
Panyakapo, 2008; Dweik et al. 2008), tires, tire fibers (Bignozzi et al. 2000; Bignozzi et al. 2002), as well as Poly(ethylene terephthalate) (Lichołai and Dębska, 2014; Dębska and Lichołai, 2015; Dębska, 2015). Cement-based materials are also modified with glass waste, sugar cane, rice husks and timber waste and its derivatives (Paris et al. 2016; Yanet al 2016.).

In recent years, obtaining concrete-like composites with wood additives has become a subject of growing interest in the construction sector (Ledhema et al. 2000). This is an answer to the requirements associated with the need to protect the environment, as wood generates significant amounts of waste that is not reused in industry. It is possible to manufacture boards created from waste wood bound with cement. This material is used as sound-absorbing lining for walls and ceilings. The authors of the article "The implementation of wood waste ash as a partial cement replacement material in the production of structural grade concrete and mortar: An overview" (Ban \& Ramli 2011) have demonstrated that waste-wood ash can be used effectively as a substitute for cement in the production of construction concrete of the appropriate classes of strength and durability. Wood waste can also be a filler in Wood-Plastic Composites (WPC), which allows obtaining the material is attractive both for technical and economic reasons (Sommerhuber et al., 2015). Another interesting material solution is the partial substitution of aggregate in concrete with cork waste obtained from the bark of Cork Oak trees (Panesar \& Shindman 2012). Torkaman et al. (2014) determined the impact of a cement matrix modified with, among others, waste wood fibre on the mechanical parameters, water absorption and density of lightweight concrete. Unfortunately, the main problem of cement-based composites containing wood waste is excessive sensitivity to water, leading to dimensional changes and general decline in durability.

This problem could turn out to be less important in composites with a polymer matrix. These include concrete and mortar resin obtained by mixing synthetic resin with aggregates and a suitably selected curing agent (Czarnecki 2010). This type of mortar is discussed in this article. Results are presented of research on epoxy mortars modified with board waste from panel underlays, containing wood fibre. The modification consisted of the substitution of sand with chipped waste in quantities of $0 \%, 10 \%, 20 \%, 35 \%$ and $50 \%$ by weight. Composites containing up to $20 \%$ of the modifier were characterised by good strength properties - also after the process of cyclic freezing and thawing - and low water absorption.

\section{MATERIALS}

Epidian 5 epoxy resin was used to obtain resin mortars. Z-1 hardener (triethylenetetramine) the amount of which was $10 \%$ (by weight) compared to the amount of resin, was used to cure the resin. The selected properties of the resin and the hardener are shown in tables 1 and 2, respectively. The aggregate was quartz sand of a $0-2 \mathrm{~mm}$ grain size in accordance with the PN-EN 196-1 specification.

The modification of mortar consisted in the substitution of sand in quantities of $0,10,20,35$ and $50 \%$ vol., with chipped waste wood boards of a bulk density equal to $0.072 \mathrm{~g} / \mathrm{cm} 3$. Grain-size curves for the sand and waste material used in the study are shown in Figure 1. Determination of the grain composition was carried out in accordance with the standard PN-EN 933-1:2000. On the basis of the available literature data and our own results of a preliminary study on resin mortar, a

Table 1. Selected parameters characterizing Epidian 5 epoxy resin.

\begin{tabular}{|l|l|l|l|l|}
\hline Resin type & Density & Viscosity $25^{\circ} \mathrm{C}$ & Molecular mass & Epoxide number LE \\
\hline & $\mathrm{g} / \mathrm{cm}^{3}$ & $\mathrm{mPa} \mathrm{s}$ & $\mathrm{g} / \mathrm{mole}$ & $\mathrm{mole} / 100 \mathrm{~g}$ \\
\hline Epidian 5 & 1.17 & 30000 & 450 & 0,49 \\
\hline
\end{tabular}

Table 2. Selected physiochemical properties of Z-1 hardener

\begin{tabular}{|l|l|l|l|l|l|}
\hline Kind of hardener & Density & $\mathrm{pH}$ & Boiling temperature & Form & Water solubility \\
\hline & $\mathrm{g} / \mathrm{cm}^{3}$ & & ${ }^{\circ} \mathrm{C}$ & & \\
\hline $\mathrm{Z}-1$ & 0.981 & 12 & 277 & light yellow liquid & soluble \\
\hline
\end{tabular}




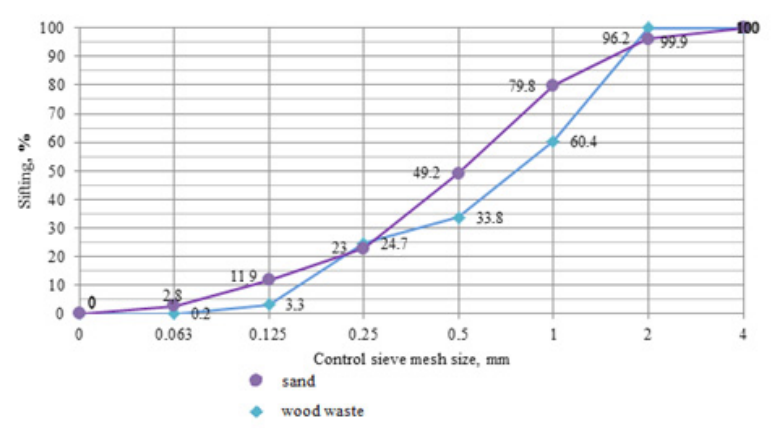

Fig. 1. Grain-size curves for wood waste and sand used for testing

mass ratio of resin to aggregates at the level of 0.25 was established. Obtaining a modifier is necessary to carry out studies on crushing of board waste (Fig. 2) forming a natural underlay under floating floors (i.e. laminate panels, three-layered boards) made from pine wood through its felting. This type of underlays under panels has the capacity for vibration-damping, levelling floors and reducing creaking of floors.

\section{METHODS}

\section{Sample preparation}

The appropriate amount of epoxy resin was weighed out and mixed thoroughly with the curing agent, forming $10 \%$ by weight of the resin weight, until a homogeneous structure was obtained. The prepared resin composition was placed into a laboratory mixer bowl and stirred with normalized sand weighed out earlier and mixed with an appropriate amount of waste, while at the same time maintaining mixing time and a constant speed of the mixers. The prepared mortar was placed in steel moulds of 40x40x160mm for strengths tests. For each composition, the samples of $60 \times 60 \times 5 \mathrm{~mm}$ were also prepared, to

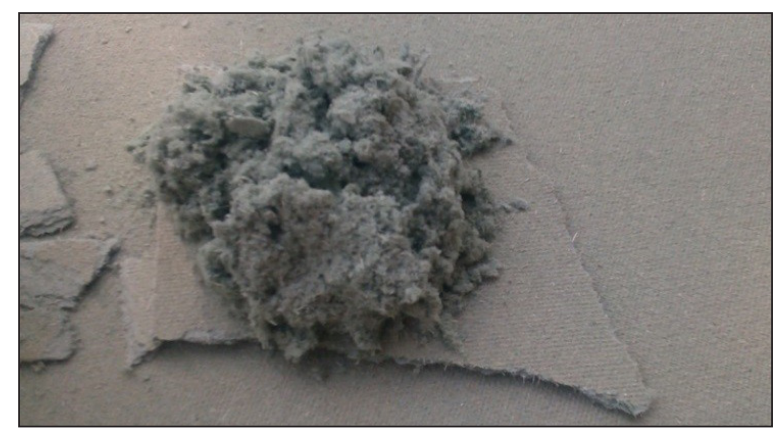

Fig. 2. Crushed waste underlay boards under floor panels study the absorption. In order to ensure that the process of curing takes place, the samples were left for 7 days under laboratory conditions. Figure 3 shows representative samples intended for strengths tests with 35-percent waste board wood. The mortar has adopted a slightly greenish hue from the waste material.

\section{Test methods}

The bending strength and compressive strength tests were carried out on endurance machines with the appropriate inserts (Fig. 4), in accordance with the standard PN-EN 196-1:2006.

For testing the compressive strength two halves were created from the trabeculae after the bending strength test.

A freezing resistance test was carried out in 50 cycles of freezing-thawing $\left(-10^{\circ} \mathrm{C}\right.$ for 2 hours

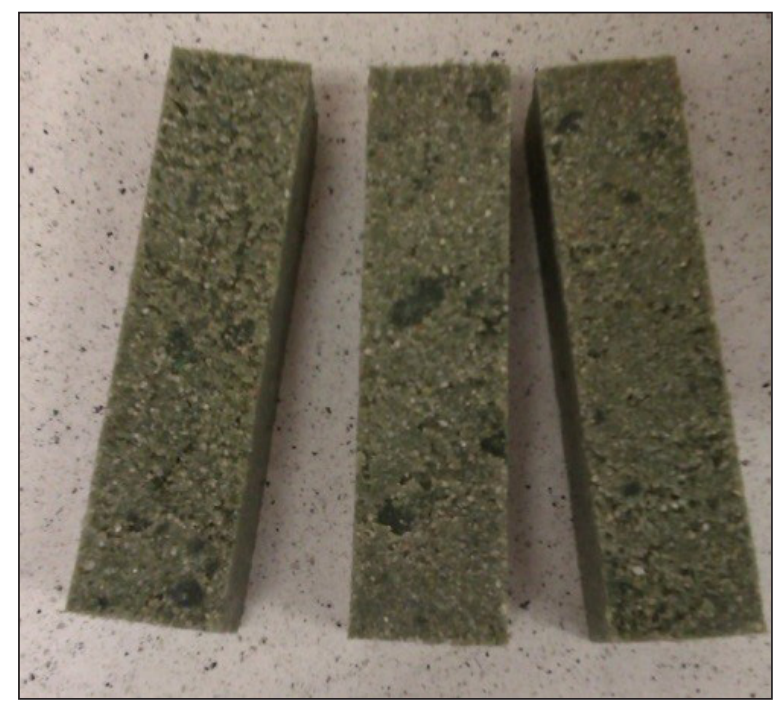

Fig. 3. Samples intended for endurance tests with 35-percent waste board wood

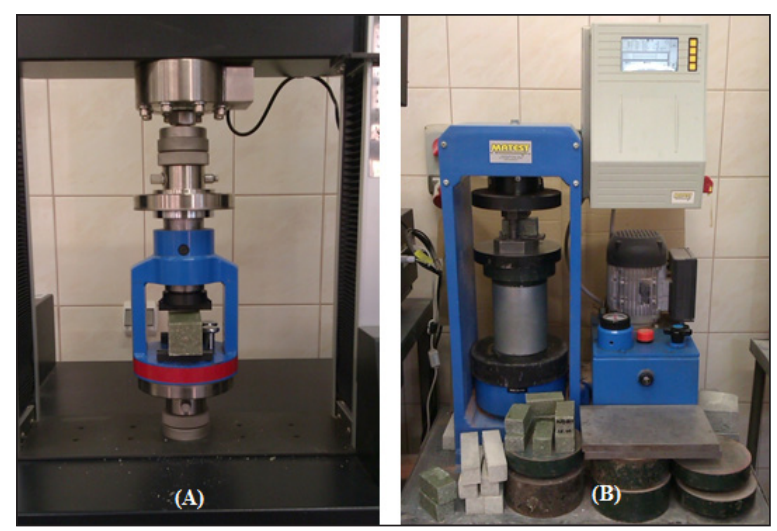

Fig. 4. Insert to test bending (A) and compressive (B) strengths 
and then $+10^{\circ} \mathrm{C}$ for 2 hours) with samples of mortar in air in a climatic chamber, and then their bending and compressive strengths was checked.

Determination of the water absorption of mortar samples subjected to exposure to water was performed according to the PN-EN ISO 175:2002 standard. In addition, an assessment of the macroscopical colour and appearance of the surface of the samples was carried out. After drying the samples at a temperature of $50 \pm 2^{\circ} \mathrm{C}$ and establishment of a constant weight, they were weighed and placed in a container with water at a temperature of $23 \pm 2^{\circ} \mathrm{C}$ (Fig. 5). The percentage change in weight was determined by immersion of samples and weighing them for another seven days, and then after 14 days.

For each sample, the change in weight (c) was calculated on the basis of the following formula:

$$
c=\frac{m_{2}-m_{1}}{m_{1}} \times 100 \%
$$

where: $m_{1}=$ is the weight of the sample, expressed in milligrams $(\mathrm{mg})$, after initial drying, before immersion in water;
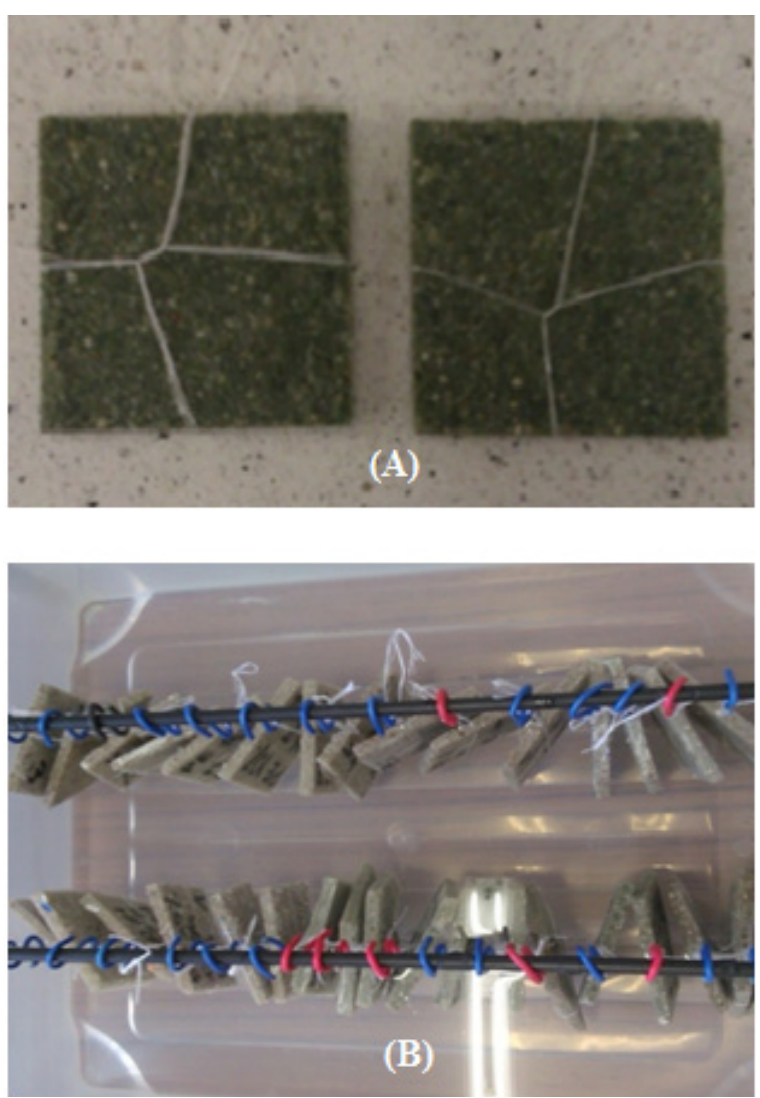

Fig. 5. Appearance of samples for testing water absorption before (A) and after (B) immersion in water $\mathrm{m}_{2}=$ is the weight of the sample, expressed in milligrams (mg), after a given duration of immersion in water.

The end result was designated as the arithmetic mean of the three values obtained for the three samples tested at the end of this same duration of immersion.

Determination of volume density was conducted according to PN-85/B-04500:1985 standard, for the samples with dimensions of $40 \mathrm{x}$ $40 \times 160 \mathrm{~mm}$. The weight of the trabeculae was marked on the technical scales. The volume of the samples was calculated on the basis of their dimensions. The volumetric density value was set in $\mathrm{g} / \mathrm{cm}^{3}$ according to the formula (2):

$$
\rho=m / V
$$

where: $\rho=$ the volumetric density, $\mathrm{g} / \mathrm{cm}^{3}$;

$m=$ the mass of the test sample, $\mathrm{g}$;

$V=$ the volume of the sample, $\mathrm{cm}^{3}$.

\section{RESULTS AND DISCUSSION}

\section{Bending and compressive strength before and after test of freezing resistance}

Figure 6 shows the dependence of bending strength of epoxy mortar before and after the test of freezing resistance on the percentage of waste wood fibre.

While analysing the results of testing the bending strength before the test of freezing resistance shown in Figure 6, we can see that 10\% substitution of sand with waste board wood causes a significant increase in the parameter in relation to the unmodified mortars. The strength increased by $4.98 \mathrm{MPa}$ representing $23.6 \%$ of the value of

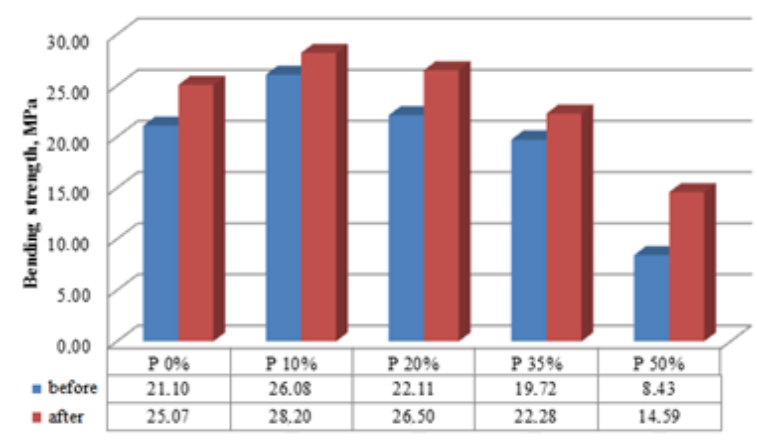

Fig. 6. The relationship between the bending strength of polymer mortars and the percentage of wood waste before and after the test of freezing resistance 
these characteristics recorded for samples containing a modifier. A further increase in the content of the waste already caused reduction in the endurance parameters, but with $20 \%$ substitution, the bending strength equal to $22.11 \mathrm{MPa}$ was still higher than the value of $21.1 \mathrm{MPa}$ obtained for unmodified mortar. Only at 50\% addition of waste wood did the panel significantly reduce the strength of the mortar to the level of $8.43 \mathrm{MPa}$, or by as much as $60 \%$. However, even then, bending strength is higher than is the case with cementbased mortars, for which the value of this parameter is a maximum of 7.2 MPa. The trend observed for samples not subjected to recurring freezing and thawing is repeated in the case of the tested samples of freezing resistance. However, the differences in relation to the unmodified mortars are lower in this case. At the same time, we can notice a slight improvement in the strength of the samples that were treated with low temperature compared to the performance of samples before testing freezing resistance. After this experiment, samples containing $50 \%$ modifier were characterized by an increase in the strength of more than $6 \mathrm{MPa}$. This fact can be explained by an increase in the stiffness of the material. The water emitted during testing partially penetrated the structure of the waste causing it to swell.

Figure 7 shows the dependence of compressive strength before and after the test of freezing resistance on the percentage of waste wood fibre.

Compressive strength, both before and after the study of freezing resistance, decreases with increasing content of waste board wood, slightly at first, and at a modifier content of $50 \% \mathrm{w} / \mathrm{w}-$ very significantly. The operation of low temperature also causes a reduction in compressive

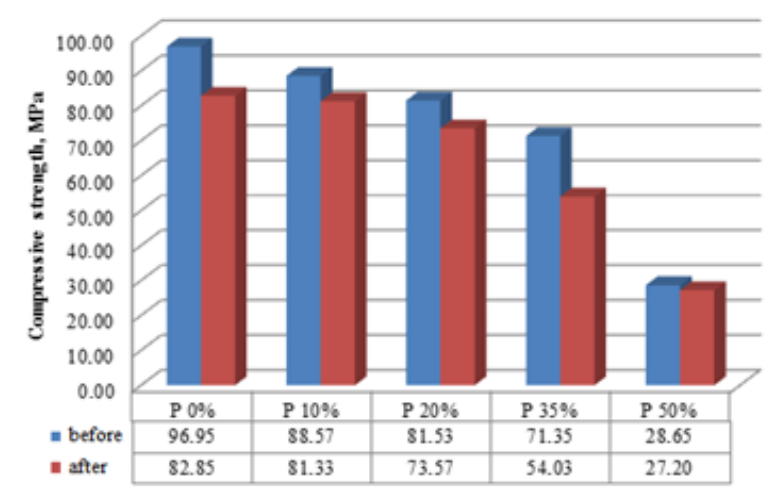

Fig. 7. The relationship between compressive strength of polymer mortars and the percentage of wood waste before and after the test of freezing resistance strength. As a result of freezing resistance test, no stratification cracks were found on the surface of the samples, only samples containing $50 \% \mathrm{w} / \mathrm{w}$ of the modifier changed colour from green to brown as shown in Figure 8.

\section{Volume density}

Figure 9 shows the impact of the wood waste on the volume density of epoxy mortar. The volume density decreases with the increase in the content of the modifier. Initially, these changes are small. A significant decrease in density is observed for mortar containing $50 \% \mathrm{w} / \mathrm{w}$ waste board wood. In this case, the density was $67.72 \%$ of the density of unmodified mortars. At the same time, volume density for all the compositions obtained is lower than the density of cement mortar.

\section{Water absorption}

The results obtained during the test of water absorption are shown in Figure 10. During the first 3 days, the absorption reached the highest increase. For mortars in which modifiers were not used this increase was around $82 \%$; with $10 \%$

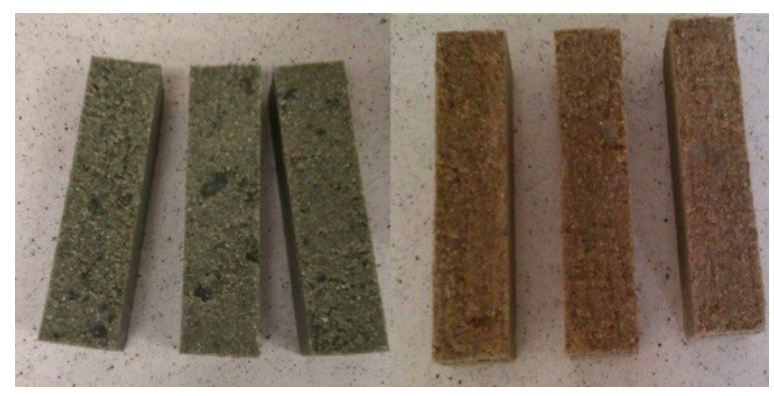

Fig. 8. The appearance of samples before and after the test of freezing resistance

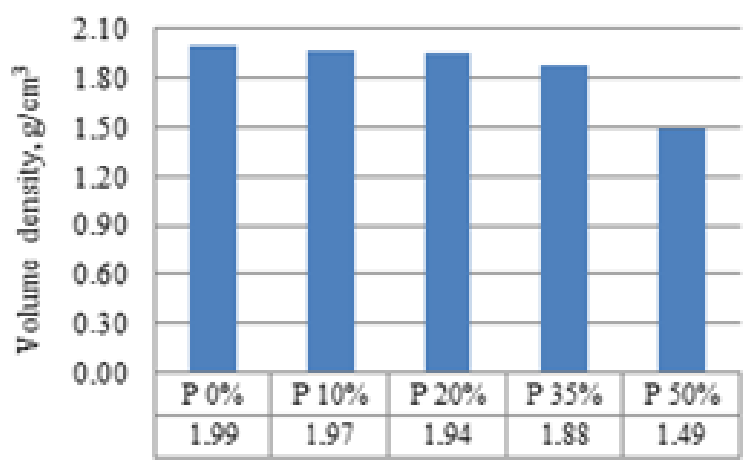

Fig. 9. Dependence of medium volumetric density of hardened polymer mortars on the percentage of waste board wood 


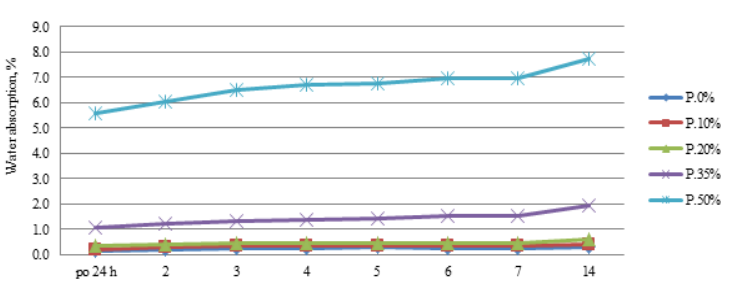

Figure 10. The dependency of water absorption of polymer mortars on the percentage of wood waste and the duration of the immersion

modifier content - approximately $87 \%$; for samples with $20 \%$ content of waste wood modifier $99 \%$; with $35 \%$ modifier $-82 \%$. In the case of wood waste content amounting to $50 \% \mathrm{w} / \mathrm{w}$ of wood waste the absorption growth was around $90 \%$. In consecutive days, variations in absorption could be observed, the largest ones for the mortars in which the contents of the modifier were $35 \%$ and $50 \%$. On the first day of the tests, the highest absorption value was equal to $5.4 \%$, observed for mortar with $50 \%$ waste wood. After 14 days of observation, the highest absorption value $(7.84 \%)$ also characterised the samples of $50 \%$ modifier. In turn, the lowest water absorption throughout the period of the tests was a characteristic of mortar without the addition of the modifier $(0.12 \%)$. Analysing the results obtained, it can be concluded that even a small addition of waste wood caused an increase in water absorption. However, even the addition of wood waste up to $35 \%$ allowed the obtaining of a mortar characterised by a much lower water absorption value than ordinary cement mortar (the absorption range for cement-based mortars is $4-10 \%$ ). Absorption increases with the amount of modifier added, which is much more absorbent than siliceous aggregates.

\section{CONCLUSIONS}

On the basis of the tests conducted and the obtained results of the analysis, the following conclusions can be made:

1. A small addition of waste board wood (up to $20 \% \mathrm{w} / \mathrm{w}$ ) causes an increase in bending strength of epoxy mortar. Strength values for samples containing $10 \%$ and $20 \%$ were respectively $22.11 \mathrm{MPa}$ and 26.08 MPa.

2. Compressive strength decreases with increasing amounts of added modifier.
3. $50 \%$ extra modifier in the form of wood fibre causes a significant deterioration of the mechanical properties of the composites. The values of the strength of the mortar, which contains $50 \%$ waste wood are: flexural $8.43 \mathrm{MPa}$, and compression $28.65 \mathrm{MPa}$.

4. During testing of the samples subject to the operation of variable thermal conditions, an increase was observed in the flexural strength and a decrease in the compressive strength. In the case of testing the flexural strength, the largest increase of this parameter was observed for samples with $50 \%$ modifier and this it amounted to $6.16 \mathrm{MPa}$. For the compressive strength, the biggest decline, equal to $17.32 \mathrm{MPa}$, was noted for samples containing 35\% w/w waste.

5. A change was observed in the colour of samples subjected to thermal processes (from green to light brown), especially those that contained $35 \%$ and $50 \%$ wood waste; however, the surface of one of the samples was not damaged.

6. In studies of water absorption, in samples characterised by a lack of wood waste or with a small amount (up to $20 \% \mathrm{w} / \mathrm{w}$ ), an increase was observed in water absorption, which slowly stabilised at a level of $0.5 \%$. However, in the case of larger quantities of added modifier (above $35 \% \mathrm{w} / \mathrm{w}$ ) water absorption continued to increase rapidly, reaching the extreme case of a value equal to 7.74 percent.

7. When preparing samples of mortar, deterioration was noted in their workability in proportion to the increase in the content of wood waste.

8. The use of wood wastes as epoxy mortar modifiers allows us to obtain a mortar with good physical and mechanical characteristics, which at the same time offers environmental benefits.

\section{REFERENCES}

1. Amianti, M. \& Botaro, V.R. 2008. Recycling of EPS: A new methodology for production of concrete impregnated with polystyrene (CIP). Cement and Concrete Composites 30, 806-814.

2. Ban, C.C. \& Ramli, M. 2011. The implementation of wood waste ash as a partial cement replacement material in the production of structural grade concrete and mortar: An overview. Resources, Conservation and Recycling 55, 669-685. 
3. Bignozzi, M.C., Saccani, A. \& Sandrolini, F. 2000. New polymer mortars containing polymeric wastes. Part 1. Microstructure and mechanical properties. Composites Part A: Applied Science and Manufacturing 31, 97-106.

4. Bignozzi, M.C., Saccani, A. \& Sandrolini, F. 2002. New polymer mortars containing polymeric wastes. Part 2. Dynamic mechanical and dielectric behavior. Composites Part A: Applied Science and Manufacturing 33, 205-211.

5. Choi, N.W. \& Ohama, Y. 2004. Development and testing of polystyrene mortars using waste EPS solution-based binders. Construction and Building Materials 18, 235-241.

6. Czarnecki, L. 2010. Polymer concretes. Cement Lime Concrete 2, 63.

7. Czarnecki, L. 2013. Sustainable Concrete; Is Nanotechnology the Future of Concrete Polymer Composites. Advanced Materials Research, 687, Ed. Ru Wang and Zhenghong Yang, Trans Tech Publications Ltd, 3.

8. Czarnecki, L., \& Justnes, H. 2012. Sustainable and Durable Concrete. Cement Lime Concrete 6, 341.

9. Czarnecki, L., Kaproń, M., Piasecki, M. \& Wall, S. 2012. Budownictwo zrównoważone budownictwem przyszłości. Inżynieria i Budownictwo. 1, 18.

10. de Assuncao, R.M.N., Royer, B., Oliveira, J.S., Filho, G.R. \& de Castro Motta, L.A. 2005. Synthesis, characterization and application of the sodium poly(styrenesulfonate) produced from waste polystyrene cups as an admixture in concrete. Journal of Applied Polymer Science 96, 1534-1538.

11. Dębska, B. 2015. Modification of Polymer Composites by Polyethylene Terephthalate Waste. In P.M. Visakh and M. Liang, Eds., Poly(ethylene Terephthalate) Based Blends, Composites and Nanocomposites. Elsevier, Inc., p. 195.

12. Dębska, B. \& Lichołai, L. 2015. The selected mechanical properties of epoxy mortar containing PET waste. Construction and Building Materials 94, 579.

13. Dweik, H.S., Ziara, M.M. \& Hadidoun, M.S. 2008. Enhancing concrete strength and thermal insulation using thermoset plastic waste. International Journal of Polymeric Materials 57, 635-656.

14. Fowler, D.W., Sander, D. \& Carrasquillo, R.L. 1995. The behavior of Portland cement concrete with the incorporation of waste plastic fillers. Disposal and Recycling of Organic and Polymeric Construction Materials 1, 61-74.
15. Ledhema, A., Dheilly, R.M., Benmalek, M.L. \& Qu'eneudec, M. 2000. Properties of wood-based composites formulated with aggregate industry waste. Construction and Building Materials 14, 341-350.

16. Lichołai, L. \& Dębska, B. 2014. A study of the effect of corrosive solutions on selected physical properties of modified epoxy mortars. Construction and Building Materials 65, 604.

17. Mounanga, P., Gbongbon, W., Poullain, P. \& Turcry, P. 2008. Proportioning and characterization of lightweight concrete mixtures made with rigid polyurethane foam wastes. Cement and Concrete Composites 30, 806-814.

18. Palos, A.; D’Souza, N.A., Snively, C.T. \& Reidy III, R.F. 2001. Modification of cement mortar with recycled ABS. Cement and Concrete Research 31, 1003-1007.

19. Panesar, D.K. \& Shindman, B. 2012. The mechanical, transport and thermal properties of mortar and concrete containing waste cork. Cement \& Concrete Composites 34, 982-992.

20. Panyakapo, P. \& Panyakapo, M. 2008. Reuse of thermosetting plastic waste for lightweight concrete. Waste Management 28, 1581-1588.

21. Paris, J.M., Roessler, J.G., Ferraro, C.C., DeFord, H.D., \& Townsend, T.G. 2016. A review of waste products utilized as supplements to Portland cement in concrete. Journal of Cleaner Production 1-18.

22. Runkiewicz, L. 2010. Realizacja obiektów budowlanych zgodnie z zasadami zrównoważonego rozwoju. Przegląd budowlany 2, 17-23.

23. Schmidt, H. \& Cieślak, M. 2008. Concrete with carpet recyclates: Suitability assesment by surface energy evaluation. Waste Management 28, 1182-1187.

24. Sommerhuber, P.F., Welling, J. \& Krause, A. 2015. Substitution potentials of recycled HDPE and wood particles from post-consumer packaging waste in Wood-Plastic Composites. Waste Management.

25. Torkaman, J., Ashori, A. \& Momtazi, A.S. 2014. Using wood fiber waste, rice husk ash, and limestone powder waste as cement replacement materials for lightweight concrete blocks. Construction and Building Materials 50, 432-436.

26. Yan, L., Kasal, B. \& Huang, L. 2016. A review of recent research on the use of cellulosic fibres, their fibre fabric reinforced cementitious, geopolymer and polymer composites in civil engineering. Composites Part B, doi:10.1016/j.compositesb.2016.02.002. 